\title{
18. SEDIMENTOLOGY, PETROLOGY, AND CYCLIC SEDIMENTATION PATTERNS, WALVIS RIDGE TRANSECT, LEG 74, DEEP SEA DRILLING PROJECT ${ }^{1}$
}

\author{
Peter E. Borella, Saddleback College, Mission Viejo, California, and Scripps Institution of Oceanography, \\ La Jolla, California
}

\begin{abstract}
Shallow- to deep-water environments are represented by the sediments and rocks recovered from the Walvis RidgeAngola Basin transect. These calcareous oozes, chalks, limestones, and volcaniclastic sedimentary rocks are used to define and correlate four lithostratigraphic units. The sediments were deposited in cycles which represent recurring tectonic or oceanographic events and may be related to climatic fluctuations and orbital perturbations.

Turbidites are the most common and easily identified sedimentary cycle. They are Late Cretaceous to Paleocene in age and are repeated in intervals ranging from thousands to tens of thousands of years. They are also found interbedded between basalt layers. Turbidites are easily distinguished from the other cycles present by their sedimentary structures, mineral composition, alteration products, and physical properties (GRAPE) data. Large-scale turbidites, debris, or slump breccias are found at or just above the Cretaceous/Tertiary boundary and indicate an event of considerable energy possibly related to intense tectonic activity.

Diagenetic cycles, interpreted as small-scale dissolution cycles or sequences produced by biogenic activity, occur in early Paleocene chalks. The recurrence intervals average $\sim 20,000 \mathrm{y}$. but have a wide range of values. Variations in $\mathrm{CaCO}_{3}$ content, color, gradational boundaries, and trace fossil content characterize these sediments. These cycles reflect bottom-water conditions.

Ooze-chalk cycles occur in upper Oligocene to upper Paleocene sediments and represent conditions that once existed at the sediment/water interface where they obtained their diagenetic potential. These oscillations are repeated over tens of thousands of years and may have no modern analogs.

Color variations in sediments at the Cretaceous/Tertiary boundary indicate local fluctuations in oxygen content within the sediments or the water column. This situation lasted for several hundred thousand years and is not repeated elsewhere in the sequence.

Large dissolution cycles are recorded in the sediments at Site 527 that are of middle Miocene and early Oligocene to middle Eocene age. During this time the seafloor at this site appears to have been located at or subsided to a depth occupied by a fluctuating CCD and lysocline.
\end{abstract}

\section{INTRODUCTION}

Five closely spaced sites were drilled along a traverse from the crest of the aseismic Walvis Ridge into the Angola Basin to the north. The present depths of the sites range from $1054 \mathrm{~m}$ at the crest to $4428 \mathrm{~m}$ within the Angola Basin (Fig. 1). All sites presently lie beneath surface currents located in the eastern part of the central subtropical gyre and are well inside the main flow of the Benguela Current and associated upwelling zones. The shallowest site (526) lies presently within the water depths occupied by Antarctic Intermediate Waters; the remainder of the sites lie at depths dominated by the North Atlantic Deep Water (NADW).

Structurally the Walvis Ridge is a series of offset north-northwest trending crustal blocks connected by east-northeast trending blocks. These sets of blocks form a roughly linear ridge which extends to the northwest and joins the continent of Africa near $20^{\circ} \mathrm{S}$ latitude. In the study area, these structural blocks slope gradually into the Angola Basin to the northwest and more steeply into the Cape Basin that lies to the southeast (Moore et al., 1983). The topography of the Walvis Ridge is such that it presently isolates the Angola Basin from the Antarctic Bottom Waters (AABW) which

\footnotetext{
${ }^{1}$ Moore, T. C., Jr., Rabinowitz, P. D., et al., Init. Repts. DSDP, 74: Washington (U.S.
} Govt. Printing Office). dominate the deep waters of the Cape Basin. The Angola Basin is thus dominated by NADW and as a consequence the calcium carbonate compensation depth in this area of the eastern South Atlantic is about $1 \mathrm{~km}$ deeper than in the western South Atlantic.

\section{PURPOSE AND PROCEDURES}

The major aim of this paper is to integrate a study of the sediments and sedimentary rocks with the results of the GRAPE, grain size, carbon-carbonate, and carbonate bomb data. The procedures and methods used in obtaining these results are described in detail in many volumes of the Initial Reports (e.g., Bader and Gerard, 1970; Boyce and Bode, 1972). In addition, a total of 125 thin sections were prepared from sediment and sedimentary rocks for microscopic analysis following the procedure outlined in Borella, et al. (1982). Lastly, a detailed megascopic investigation of the cores and color slides of the cores was performed to decipher the varieties of cyclic sedimentation patterns which were observed during Leg 74. Correlation of these cyclic sedimentation patterns to the results of the aforementioned analyses follows.

\section{GENERAL SEDIMENTOLOGY AND STRATIGRAPHY}

The majority of sediments recovered from Leg 74 sites are foraminifer-nannofossil oozes and chalks. 




Figure 1. Index map and site locations, Walvis Ridge-Angola Basin transect, Sites 526-529.

Four major lithologic units were recognized and are discussed in descending order downhole.

Unit I consists of nannofossil and foraminifer-nannofossil oozes that dominate the upper $150-250 \mathrm{~m}$ in each hole (Fig. 2-6, back pocket) and can be correlated from hole to hole, indicating a uniform and similar sediment source within the study area since the late Oligocene. $\mathrm{CaCO}_{3}$ content is greater than $90 \%$. The only exception to this is found at the base of Unit I at Site 527, where pelagic clay is found in two distinct beds (Fig. 6). $\mathrm{CaCO}_{3}$ content within these clay-rich beds is less than $20 \%$. Preliminary findings indicate that these beds are the result of dissolution and represent a fluctuating calcium carbonate compensation depth (see section on dissolution cycle, this chapter). Primary and secondary sedimentary structures are very poorly preserved in the oozes and could not be used to determine if any slump deposits were cored. However, a few slumps were identified by precise biostratigraphic age determination (see site chapters, this volume).

Uppermost Unit I grades into an alternating sequence of ooze and chalk (Unit II) for approximately $100 \mathrm{~m}$, with ooze dominant at the top and chalk dominant to- ward the base of the unit. $\mathrm{CaCO}_{3}$ content still exceeds $90 \%$ and some sedimentary structures are preserved in the chalks. Stratigraphically the ooze/chalk sequence can be correlated from site to site with the exception of Site 526, the shoalest site (Fig. 2), where approximately $30 \mathrm{~m}$ of chalk alternating with ooze is found. The ooze/ chalk sequence has an age ranging from early Oligocene to late Paleocene at the three intermediate-depth Sites 525,529 , and 528 (Fig. 3, 4, and 5, resepectively). During the early Oligocene to late Eocene, Site 526, which is located on another crustal block (Rabinowitz and Simpson, 1979) was close to sea level. The presences of shallow-water fossils (e.g., oysters, pelecypods) and algal oncolites (see Frontispiece, Fig. 7) along with a graded sequence of rubbly limestones interpreted as a channel fill, support a high-energy, shallow-water environment (Fig. 7A). Oncolites (Fig. 7B) are formed by blue-green algae, indicating an origin in the photic zone of the water column. Oozes and chalks could not accumulate because of the winnowing action of waves and currents. The basal portion of the ooze/chalk sequence found at the deepest Site 527 has an age of late Paleocene, which agrees well with the intermediate-depth sites. However, 

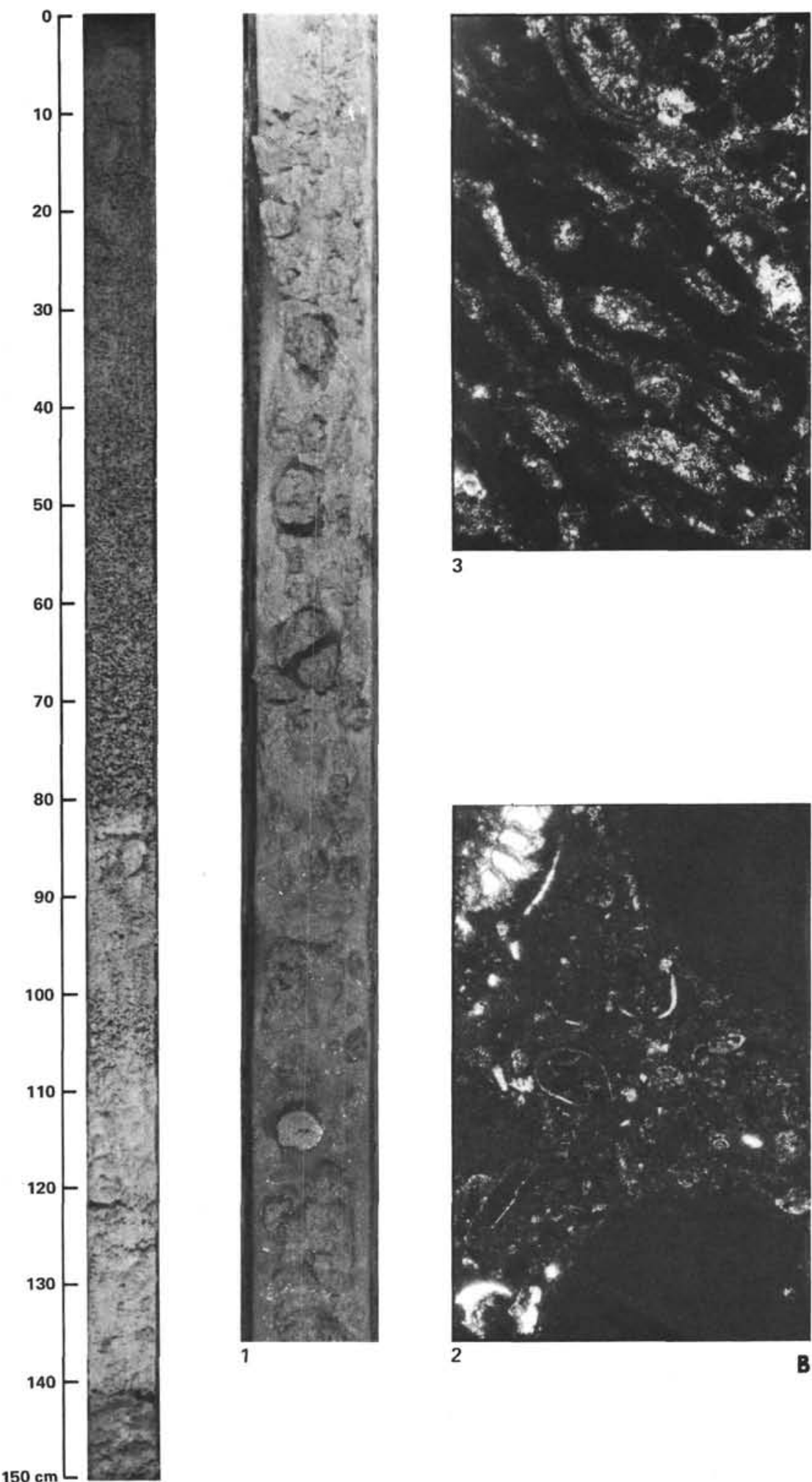

3

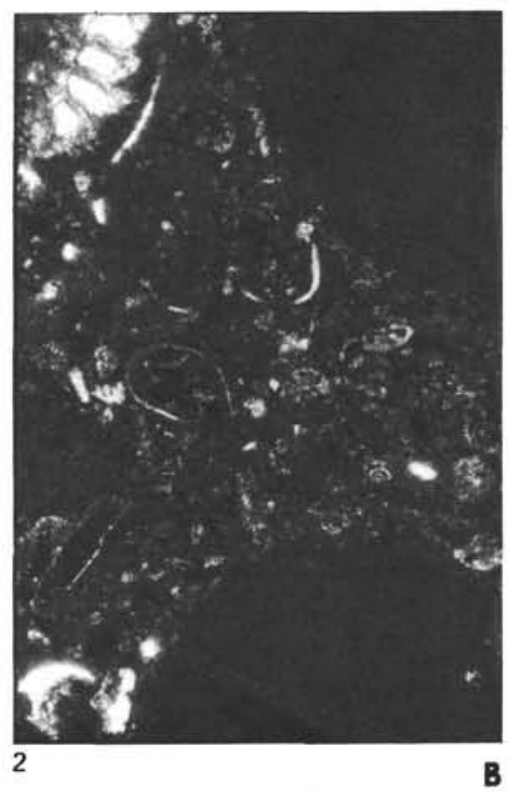

A

Figure 7. A. HPC-cored Section 526A-46-1. Note the grading in carbonate rubble, interpreted to be a channel fill or turbidite. Carbonate components include algal fragments, oncolites, oyster shells, crinoids, and bryozoans. B. (1) HPC-cored Sample 526A-45-2, $30-100 \mathrm{~cm}$. Carbonate sands and rubble containing large rounded oncolites. (2) Sample $526 \mathrm{~A}-45-2,40-42 \mathrm{~cm}$. Microphotograph of oncolites showing included fecal pellets and fossil hash. Foraminifers and ostracods were identified within the concentric oncolites. (3) Sample 526C-9-1, 4-7 cm. Algal oncolite within a coquina sandstone. Note fossil hash and recrystallized calcite (neomorphic sparite). For 2 and 3, horizontal field of view is $2 \mathrm{~mm}$. 
at Site 527 the Oligocene sediments are drastically reduced in thickness compared to the other sites, a reduction attributed to dissolution (see Site 527 site chapter, section on sediment accumulation rates). In addition, major biostratigraphic hiatuses have been identified within this interval (Boersma, this volume). These ooze/ chalk transitions and cycles will be discussed in detail in subsequent sections.

Unit II oozes and chalks grade into Unit III chalks and highly indurated chalks underlain by basement basalt. $\mathrm{CaCO}_{3}$ content is variable, ranging from $20-80 \%$, and is primarily attributed to increasing amounts of volcanogenic materials, dissolution, and changing oceanographic conditions. In this unit, multicolored cyclic sedimentation patterns are most easily recognized (see Frontispiece, Fig. 5 and back pocket Fig. 8); the most conspicuous of these are many small-scale slumps and turbidites. These and other cycles are discussed in the following sections.

The increased frequency of the evidence of sediment gravity flows and volcanic activity toward the bottom of Unit III indicates a change in sedimentation from a dominantly pelagic mode to a relatively shallow water, tectonically active, volcaniclastic mode of sedimentation. Volcaniclastic layers and a few ash beds are well preserved but cannot be directly correlated from hole to hole (Simon and Schminke, this volume). Beautifully preserved primary sedimentary structures are present throughout the entire unit (see Frontispiece, Figs. 1 and 10); they include graded bedding, cross laminations, convoluted bedding, and microfaults. Biogenic sedimentary structures (Frontispiece, Fig. 10) are ubiquitous and indicate that the sediments were reworked at least once after they were deposited. Fecal pellets are commonly observed in thin section, attesting to the presence of a benthic fauna. Zoophycos, Planolites, halo burrows, and Chondrites are the most abundant ichnogenera present (Fig. 9). (See also Fütterer, "Bioturbation and trace fossils," this volume).

Unit III varies from $175 \mathrm{~m}$ thick in Hole $525 \mathrm{~A}$ to $\sim 110 \mathrm{~m}$ thick at Sites 527, 528, and 529, with ages ranging from late Paleocene to Late Cretaceous. Excluding Site 526, where Unit III chalks are absent, the chalks are easily traceable from site to site using both cores and seismic logs (see site reports, this volume). Chert nodules and beds occur in the lower portions of Unit II through Unit III but are confined to Sites 525, 528, and 529. The shallowest and deepest sites along the transect contain no chert. Individual chert deposits cannot be correlated from site to site. The chert formed as silicarich solutions that migrated through permeable layers into pockets or voids and eventually crystallized. An excellent summary of the origin and occurrence of siliceous deposits recovered from DSDP cores is given by Pisciotto (1981).

The much studied Cretaceous/Tertiary boundary occurs within Unit III (see Frontispiece, Fig. 2). At Sites $525,527,528$, and 529 the boundary is found just below brecciated zones indicating large-scale slump activity or gravity flow deposits. These zones have low carbonate concentrations and dramatic color contrasts (Figs. 3-6). The high tectonic and current activity evidenced at or slightly above the boundary may have been triggered by the same event that caused the worldwide Cretaceous/ Tertiary boundary.

Unit III at Site 526 contains calcareous sands composed of approximately $60 \%$ carbonate and $40 \%$ noncarbonate grains. The noncarbonate fraction contains angular quartz and feldspar grains (K-feldspar) as well as volcanic rock fragments. The carbonate fraction contains grains of mollusks, echinoderms, bryozoans, foraminifers, and algae. Much of this material may be contamination from above. Total penetration into these sands was only about $110 \mathrm{~m}$, with very poor recovery. Unstable hole conditions forced us to abandon the site. The true thickness of the immature sands in uncertain, but they indicate that a very shallow water, high-energy environment existed at or near Site 526 from the late Eocene to the late Paleocene.

At Sites 525, 528, and 527 (Figs. 3, 5, and 6), basement was penetrated. Beds of nannofossil chalks, limestones, mudstones, and siltstones are interbedded with the basalts. Sediment layer thicknesses range from a few centimeters to several meters. Many of the interbeds are identified as turbidites and/or small-scale slump deposits. Primary sedimentary structures and trace fossils are easily identified within these deposits. A shallowwater fauna including Inoceramus sp.? also occurs.

Shipboard interstitial pore water analyses of $\mathrm{Ca}$ and $\mathrm{Mg}$ concentrations show an inverse relationship (see site chapters and Gieskes et al., this volume). For example, at Site $528 \mathrm{Ca}$ concentration in pore waters increases from $26.3 \mathrm{mM} / 1$ above basement to $76.52 \mathrm{mM} / 1$ in the sedimentary interlayers within the basement. Conversely, magnesium decreases from $39.33 \mathrm{mM} / 1$ above basement to $1.20 \mathrm{mM} / 1$ in the basement sediment interlayThis release of $\mathrm{Ca}$ and uptake of $\mathrm{Mg}$ has been interpreted as a reaction involving the alteration of basalts in the ocean crust and/or the alteration of volcanic matter dispersed within the sediments (Gieskes, 1981; Gieskes and Lawrence, 1981, Lawrence and Gieskes, 1981; McDuff, 1981). It is also possible that this rapid exchange of elements between sediments and pore waters is due to seawater-basement interaction at elevated temperatures (Bischoff and Dickson, 1975). Magnesium is released during submarine weathering of basalt. It combines with $\mathrm{CO}_{3}{ }^{-2}$ and forms a precipitate aiding in cementation and diagenesis. Studies of the $\mathrm{Sr} / \mathrm{Ca}$ ratio in carbonates indicate that in the chalks and limestones recrystallization is nearly complete (Gieskes et al., this volume). Magnesium is thus depleted in pore waters. Calcium in contrast is enriched because of dissolution and weathering of basalt.

Petrographic evidence of early diagenesis just above and in the basement complex within both the coarsegrained and fine-grained chalks, limestones, and volcanogenic rocks includes authigenic overgrowths (Fig. 10A), recrystallization of lime mud matrix (Fig. 10B), diagenetically formed smectites (Frontispiece, Fig. 3), and devitrification and alteration of basalt intraclasts 


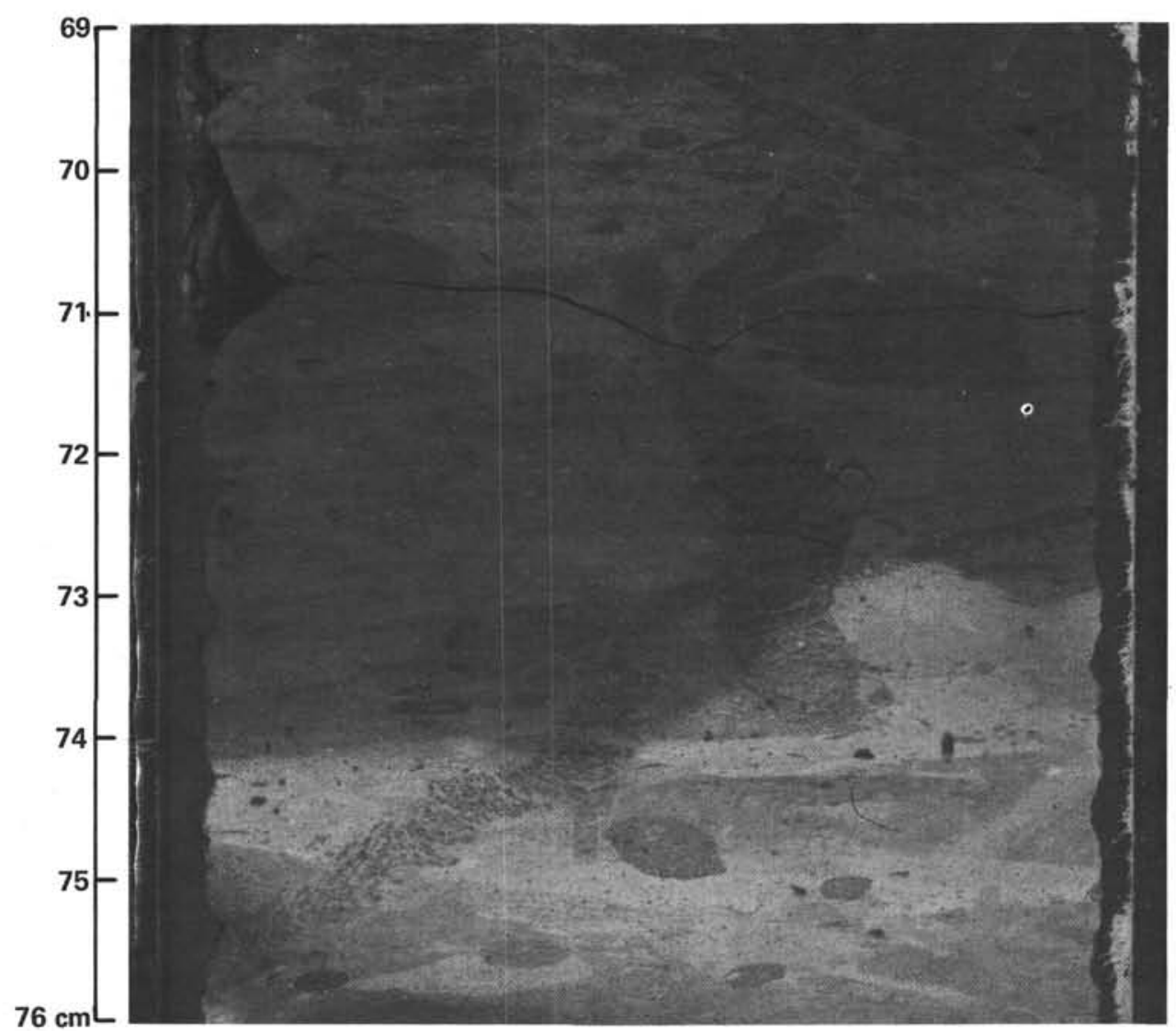

Figure 9. Sample 528-31-5, 69-76 cm. Excellent examples of preserved biogenic sedimentary structures, indicating intensity of biologic activity. Note Zoophycos at 73-75.5 cm, Planolites at 74.5 (in center) and scattered throughout, and halo burrows at $77.5 \mathrm{~cm}$.

(Fig. 10C). The basalt itself is highly altered (Fig. 10D), which further indicates interaction between interstitial waters, basalt, and sediments.

\section{CYCLIC SEDIMENTS}

\section{Sediment Gravity Flow Cycles}

The most obvious and commonly observed sedimentary cycles in the cores recovered are sediment gravity flows (turbidites, debris flows, grainflows, and subaqueous slumps), interbedded with pelagic sediment. Turbidite deposits are by far the most common type of sediment gravity flow. They are mostly confined to Units III and IV in each core and range in age from early Paleocene to Late Cretaceous.

The turbidites consist of primarily dark green, graded to horizontally laminated sands and silts overlain by light gray pelagic sediments $\left(\mathrm{T}_{\text {cde }}\right.$ and $\mathrm{T}_{\text {de }}$ of Bouma, 1962). The basal contact between the coarse turbidites and the underlying pelagic interval is usually sharp (Fig. 11). Load casts are also observed. Commonly associated with this basal contact are very thin zones or veins of altered, recrystallized, or diagenetically formed smectites, chlorite and/or zeolites (Frontispiece, Fig. 3). Some inverse graded sequences were also observed (Fig. 11, Section 528-37-2). The upper boundary of the turbidite proper with the overlying pelagic interval is generally sharp but in some instances it is gradational. The overly- ing pelagic interval (foraminifer-nannofossil chalk) is usually white to gray and is highly burrowed.

$\mathrm{CaCO}_{3}$ content in the turbidite sands and silts is low, ranging from $\sim 10-50 \%$, whereas the $\mathrm{CaCO}_{3}$ content of the adjacent pelagic interval ranges from $60-90 \%$ (Fig. 12). Based on GRAPE analysis, which is measured continuously on each section, the turbidite sands and silts are seen to have a higher porosity and a lower wetbulk density than the adjacent pelagic intervals (e.g., Fig. 11, Sections 528-37-1-4). The thickness of a turbidite couplet (turbidite and pelagic interval) ranges from $15-150 \mathrm{~cm}$. According to the sedimentation rates determined for those intervals (Shackleton, this volume) the frequency of occurrence of each event is from $6 \times 10^{3} \mathrm{y}$. to $60 \times 10^{3}$ y., respectively. Dean et al. (1978) reported that turbidites deposited off the continental margin of Northwest Africa have similar frequencies of occurrence. However, the source for the noncarbonate components in those turbidites is the continent, whereas the inferred source of the volcanogenic turbidites discussed here is the aseismic Walvis Ridge.

The coarse-grained turbidite layers contain very coarse-grained pebbles and sands as well as fine-grained silts and clays. Both carbonate and noncarbonate components are present (Fig. 13A). Most volcanic rock fragments are angular and have glassy vesicular and nonvesicular textures (Fig. 13B). Many of the volcaniclastic grains are highly altered to palagonite and smectite 




A

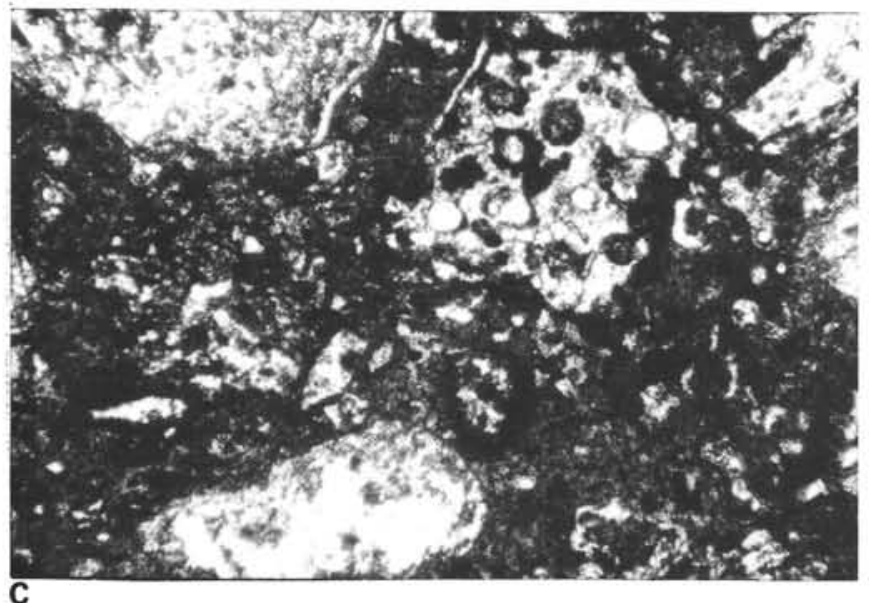

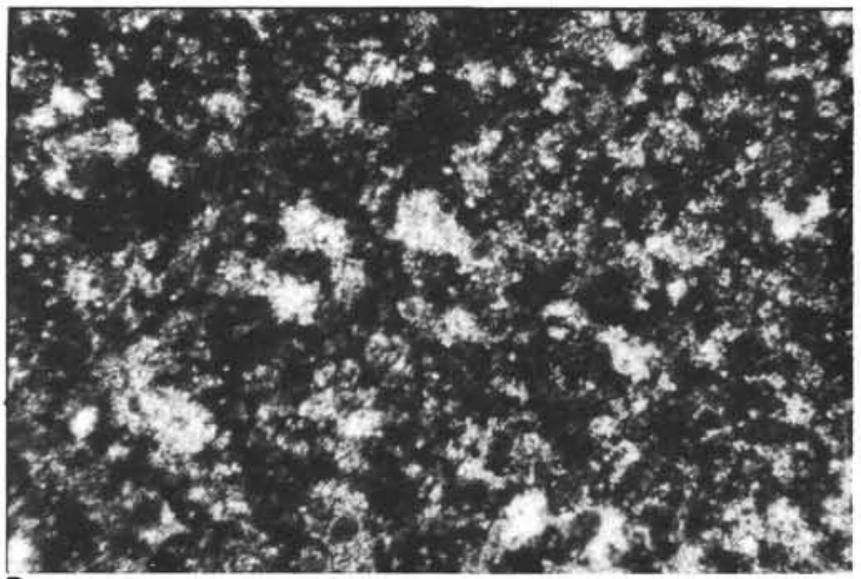

B

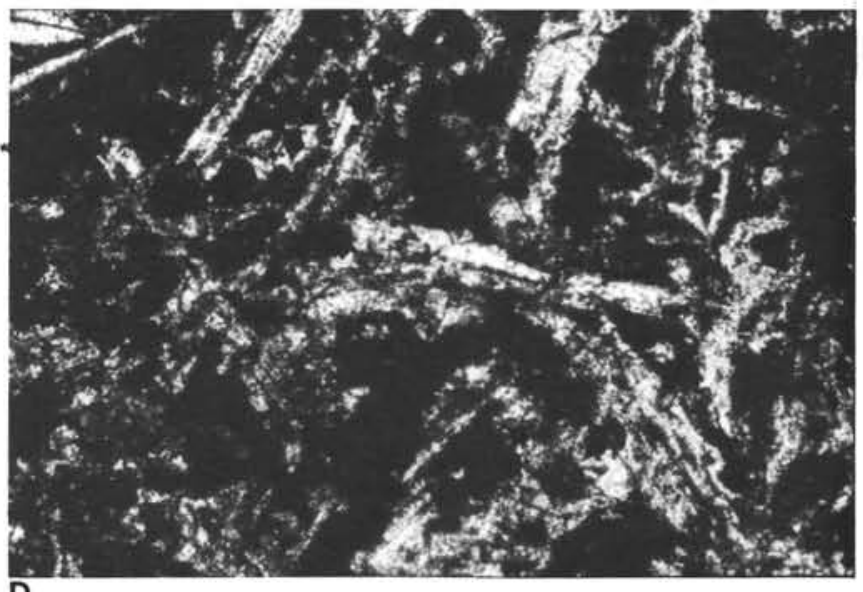

D

Figure 10. Alteration in volcaniclastic sediments. A. Sample 525A-52-3, 7-11 cm. This highly immature, coarse-grained, calcareous, volcaniclastic sandstone contains examples of authigenic overgrowth and weathered and altered volcanic rock fragments. Note carbonate mud intraclasts and fossil debris; polarized light. B. Sample 525A-55-1, 116-118 cm. This biomicrite or mudstone is found between basalt layers and is highly altered; recrystallization is most obvious; plain light. C. Sample $528-37-2,37-40 \mathrm{~cm}$. This microphotograph is a muddy volcaniclastic sandstone containing highly altered volcanic rock fragments. Note that outer boundaries of many volcanic large grains (palagonite?) are highly altered and weathered. The rock matrix is composed of fine-grained volcanic and carbonate grains; plain light. D. Sample 525A-52-2, 25-27 cm. This microphotograph is a good example of a highly altered plagioclase aphyric basalt located between sediment layers. The plagioclase laths are highly altered and appear etched; plain light. Horizontal field of view: A, $3 \mathrm{~mm}$; B-C, $2 \mathrm{~mm} ; \mathrm{D}, 0.75 \mathrm{~mm}$.

(Fig. 13A, B). Angular quartz and plagioclase feldspar grains are volcanic in origin and shown signs of submarine weathering (halmyrolosis) and alteration. K-feldspar in pumice shards may indicate more than one source for volcanic rock fragments (Simon and Schmincke, this volume) or different stages in magma evolution from the same source.

The carbonate fraction (Figure 13A) consists of angular to rounded fragments of pelmatozoans, bryozoans, brachiopods, and mollusks (large Inoceramus sp.?) as well as foraminifers. In many instances the fossil grains are fragments and are included in a mud matrix which is composed of approximately equal amounts of carbonate and noncarbonate debris. Recrystallization of carbonate grains is observed throughout. Large, rounded, mud intraclasts are also present and indicate erosion and redeposition (Fig. 13C). The polymodal sources of included grains, the high variability of tex- tures (matrix to grain-supported) and generally poor sorting of the coarse-grained volcaniclastic sediments indicate rapid deposition.

As currents lessened or where disposition was from more distal turbidites, finer-grained, laminated silts and clays were deposited (Fig. 13D). The resulting rocks are laminated biomicrites to poorly washed biosparite (Folk, 1962), or carbonate mudstones to wackestones (Dunham, 1962). Volcanic and carbonate grains are present but hard to identify. The fine-grained turbidites interbedded with basaltic rocks, are extensively recrystallized (Fig. 10B) compared to those above the basement. Diagenesis of sediments interbedded with basalt layers obviously proceeds at accelerated rates. This may be due to elevated temperatures and enhanced water circulation through the sediments at the time of lava deposition and cooling or to postdepositional hydrothermal circulation through the basalts and adjacent sediments. The chemi- 


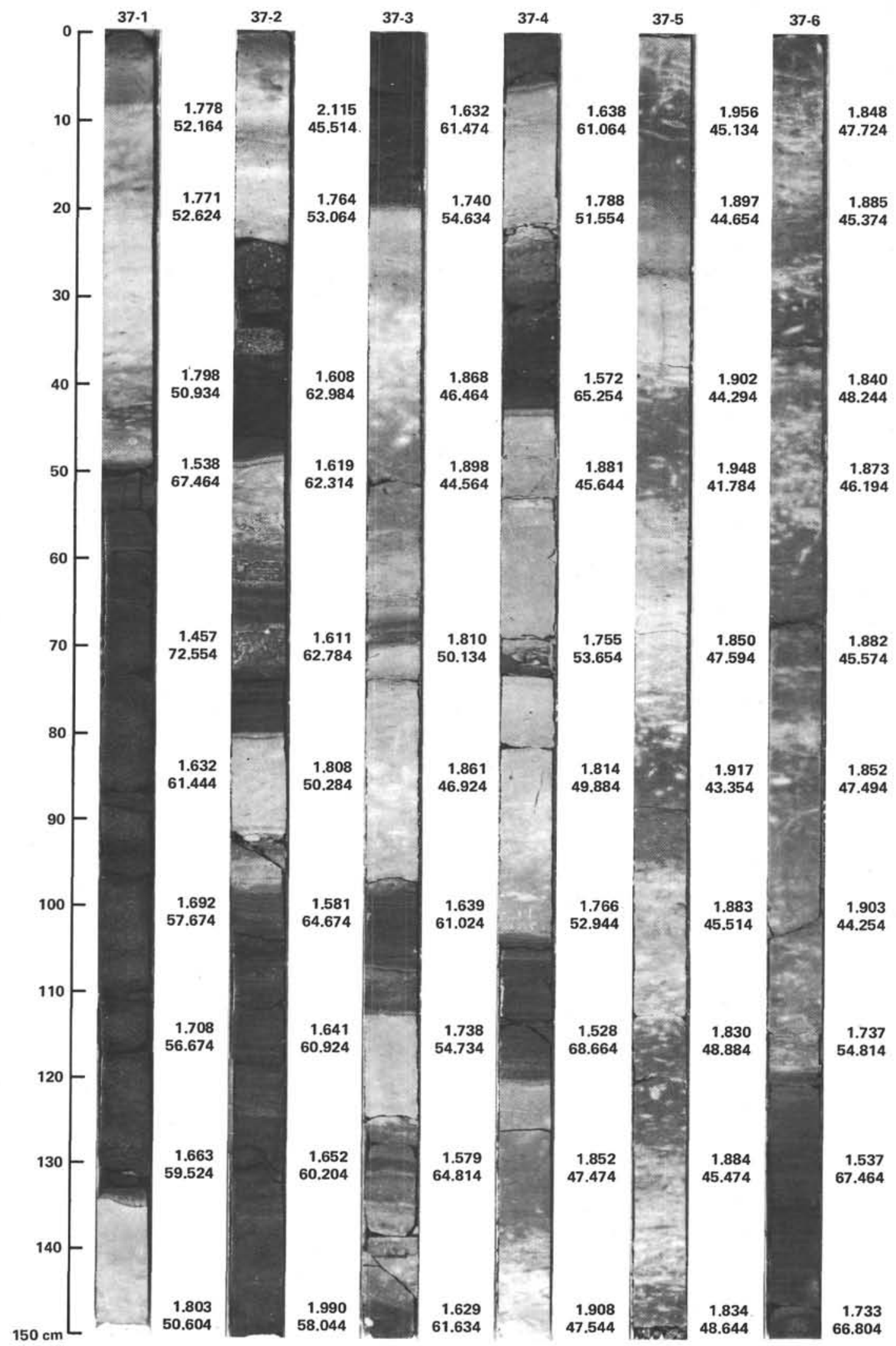

Figure 11. Turbidite cycles. Sections 528-37-1 to 528-37-4 are a series of turbidites showing load structures, graded bedding, and parallel and inclined laminations. Some inverse grading is also present in Section 2 at $25-50 \mathrm{~cm}$. The values to the right of each core section are GRAPE data. The upper value is the wet-bulk density $\left(\mathrm{g} / \mathrm{cm}^{3}\right)$ and the lower value is the porosity as a percentage. Each number represents a running average over the interval immediately above it. Sections 5 and 6 show small-scale geochemical cycles which are superimposed on the turbidite cycles. The turbidites can again be observed at the bottom of Section 528-37-6. 


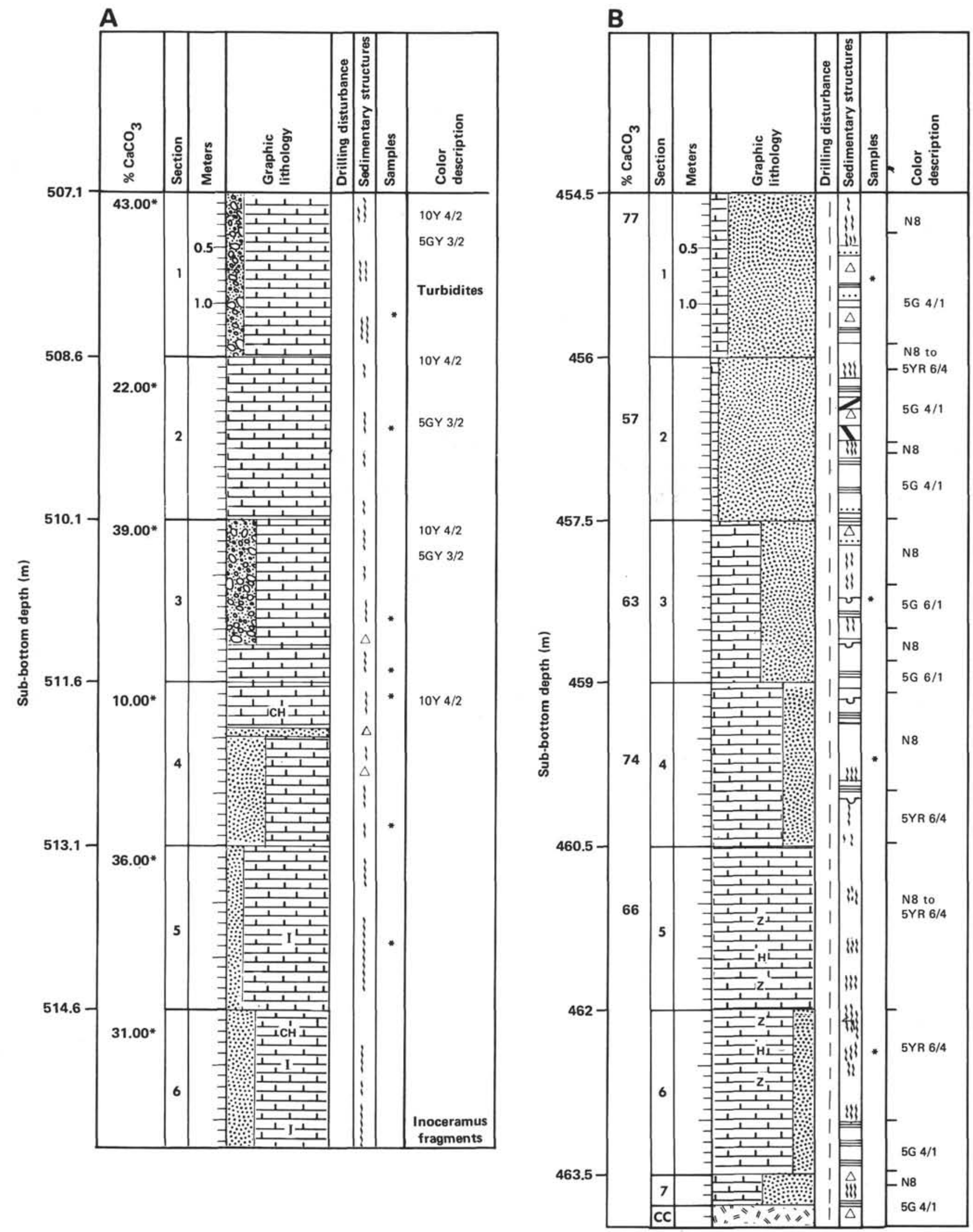

Figure 12. Comparison of $\mathrm{CaCO}_{3}$ content in turbidite and interturbidite layers in two sections. A. Core 525A-46, 507-515 m sub-bottom. B. Core 528-37, 454.5-464 m sub-bottom. The number to the left of the cores represents the percentage of $\mathrm{CaCO}_{3}$. Displaced Inoceramus shells are scattered throughout the core. 




A

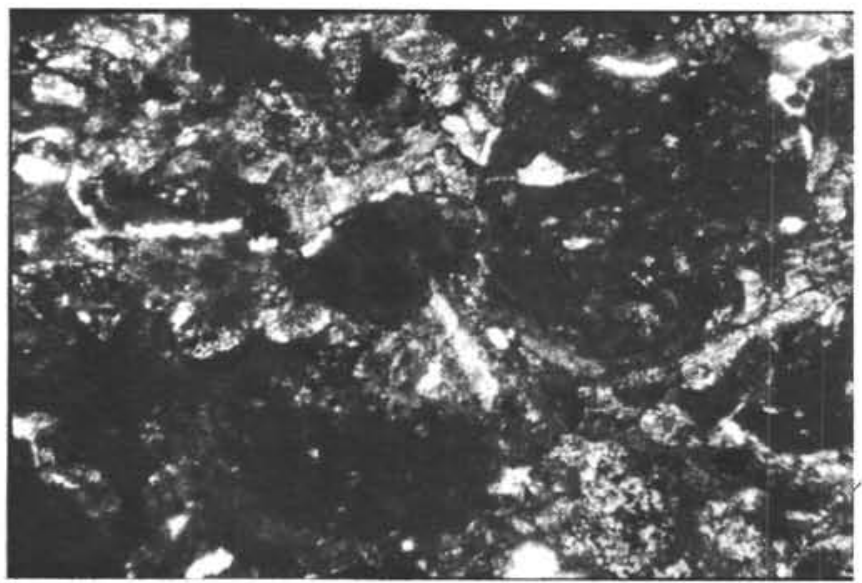

C

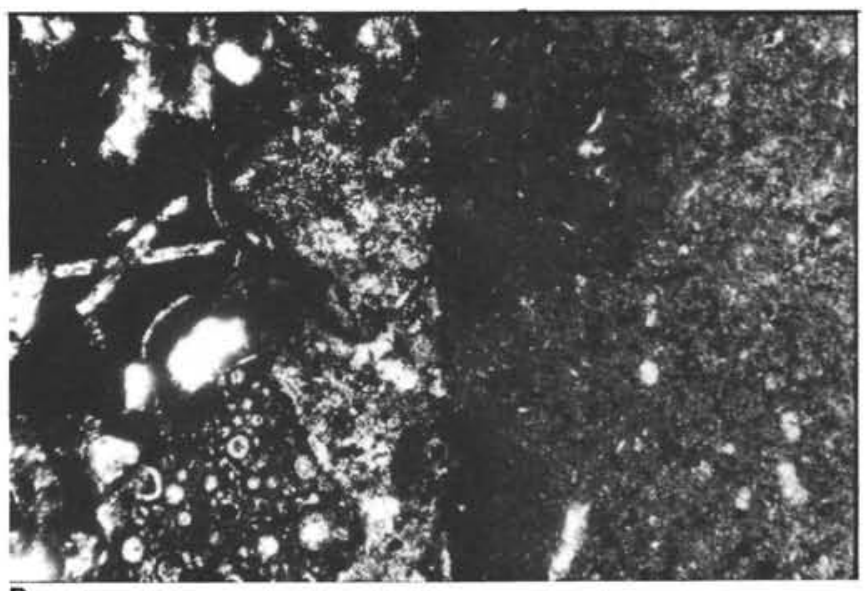

B

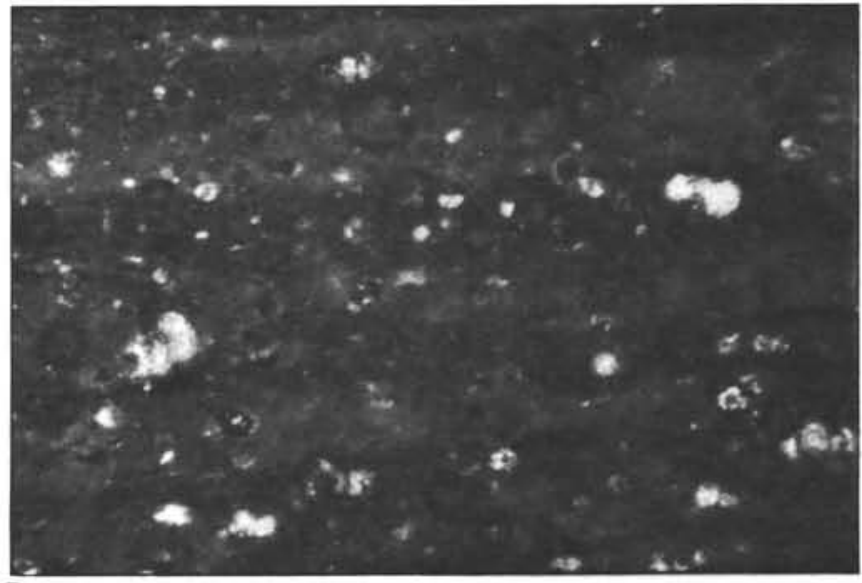

D

Figure 13. Petrography of turbidite layers. All microphotographs are taken in plain light; horizontal field of view, $2 \mathrm{~mm}$. A. Sample 525A-52-4, $12-16 \mathrm{~cm}$. A microphotograph of large pelmatozoan intraclasts mixed with rounded altered volcanic rock fragments (palagonite). The matrix is composed of carbonate and noncarbonate grains. A biointramicrudite (Folk, 1962) or wackestone (Dunham, 1962). B. Sample 528-37-1, 135-138 $\mathrm{cm}$. This microphotograph shows the basal contact of a turbidite which overlies a pelagic ooze and/or mud interval. Volcanic fragments in the overlying turbidite breccia are angular and show signs of devitrification and alterations. The pelagic interval contains approximately equal proportions of carbonate and noncarbonate materials. C. Sample 525A-52-3, 0-3 cm. This thin section (volcaniclastic-bioclastic sandstone) contains well-rounded mud intraclasts within a matrix consisting of carbonate and volcanogenic fragments. D. Sample 525A-52-4, 67-71 cm. An example of a laminated volcanogenic siltstone to mudstone within a turbidite sequence which represents the waning stages of current deposition.

cal exchange between rocks, sediments, and pore waters (Gieskes et al., this volume) explains the highly altered or "baked" appearance of these rocks as described by the shipboard scientists.

The finer-grained laminated silts and sands grade into highly bioturbated light grey to white foraminifernannofossil chalks and limestones that were deposited between periods of turbidity current activity.

Turbidites and other sedimentary gravity flow deposits in deep marine environments have been discussed by Kelts and Arthur (1981). They note that although various types of turbidites have been recognized and described in DSDP cores, many of the criteria used to distinguish turbidites (e.g., Walker and Mutti, 1973; Walker, 1967) from other deep marine deposits are not satisfactory. In particular, a major problem is to dis- tinguish thin bedded or distal turbidites from those deposits produced by winnowing by bottom currents (contourites). Where distal turbidites and contourite deposits are interbedded, distinguishing criteria are often difficult or obscured (Stow and Lovell, 1979). In fact, the original criteria used to distinguish turbidites from contourites (Hollister and Heezen, 1972; Bouma and Hollister, 1973) cannot be applied to distinguish between thin bedded silt turbidites and current-winnowed or current-transported deposits (Piper, 1973, 1978; Kolla et al., 1976; Rupke and Stanely, 1974; Stow, 1979). I suspect that both modes of sedimentation are present in the Upper Cretaceous to Paleocene deposits of the Walvis Ridge area. Until paleocirculation patterns can be determined and a detailed study of these suspected current-winnowed and current-deposited sediments is ac- 
complished, the distinguishing characteristics of contourites and thinly bedded silt and mud turbidites will remain enigmatic.

\section{Geochemical Cycles}

\section{Dissolution and/or Biogenic Cycles}

A very interesting and beautifully preserved cyclic pattern of sedimentation is observed at Sites 525, 529, and especially 528 in lower Paleocene to Upper Cretaceous sediments (See Frontispiece, Fig. 5 and back pocket Fig. 8). At Site 528 these cycles are easily distinguished from turbidites by color and physical characteristics (Figs. 11, 14). These geochemical cycles, are commonly composed of reddish brown layers alternating with light gray to white interbeds. $\mathrm{CaCO}_{3}$ content within the darker reddish beds is approximately $65 \%$; it is $75 \%$ in the lighter beds. Organic carbon content in both the dark and light layers is less than $0.1 \%$. Analysis of the GRAPE data indicates that the darker layers usually have a higher density and lower porosity than the adjacent lighter layers (Fig. 14). However, a detailed statistical treatment of the GRAPE data is needed to evaluate whether or not positive, significant correlations exist.

Both the upper the lower boundaries of these sedimentary couplets are gradational. No primary sedimentary structures were observed to indicate current activity or rapid sediment deposition. Vertical and horizontal burrows are ubiquitous in both the dark and light layers. In most instances the burrows are lighter in color than the surrounding matrix (Fig. 14). Bottom waters and sediments, during deposition, must have been well oxygenated, as evidenced by the intense bioturbation (Dean et al., 1978; Kelts and Arthur, 1981) and reddish color of the darker layers. The couplets are $\sim 40-60 \mathrm{~cm}$ thick. Based on the sedimentation rates for these intervals $\left(\sim 2.5 \mathrm{~cm} / 10^{3} \mathrm{y}\right.$.), each cycle represents $16-24$ $\times 10^{3} \mathrm{y}$.

Although a more detailed petrographic analysis is needed, a preliminary examination of several thin sections indicates that the only major difference between the light and dark layers, other than a $10 \%$ reduction in carbonate, is the $\mathrm{Fe}$ oxide which infills and surrounds many of the small fossil fragments and foraminifers in the darker layers. On the basis of fossil content, grain size, sorting, and noncarbonate components they are very similar, and both are classified as biomicrites (Folk, 1962) or mudstones (Dunham, 1962).

The origin of these cycles is uncertain. Several possibilities exist; they include contourites, distal turbidites, dissolution cycles, or cycles in the activity of bottomdwelling burrowers. Although these cycles are located in areas where definite turbidite sequences occur, they lack any of the physical criteria (i.e., sharp contacts, thin, bedded, cross-laminated, better sorted) which have been used to distinguish such deposits (Stow and and Lovell, 1979; Hollister and Heezen, 1972). Nor do they have any of the characteristics of turbidite muds or of pelagic turbidites as described by Kelts and Arthur (1981). These cycles are also very regular in their occurrence $\left(\sim 20 \times 10^{3}\right.$ y. $)$, and coincide nicely with the orbital cycle of the precession of the equinoxes $\left(\sim 23 \times 10^{3} \mathrm{y}\right.$.), first suggested as a cause of paleoclimatic fluctuations by Milankovitch (1938) and later by Hays and others (1976).

Small-scale dissolution cycles associated with regular periods of more vigorous bottom-water circulation and enriched oxygen content seem more reasonable. Welloxygenated bottom waters are indicated by the reddish brown color and the high biogenic activity. Ramsay (1974) suggests that warm periods are associated with high productivity and possibly increased ocean mixing. This produces increased removal of carbonate by organisms, deposition of carbonates in high latitudes, enhanced solution of calcareous tests, and an elevated CCD in mid-latitudes. Thus in the mid-latitude Walvis Ridge area reddish sediments containing less carbonate would accumulate. Cold periods, on the other hand, correspond to periods of low surface productivity, which in high latitudes lead to a decrease in the diversity of $\mathrm{CaCO}_{3}$ species and a reduction in the rate of carbonate dissolution. In mid-latitude areas the changes in surface productivity are reflected by a decrease in the rate of carbonate dissolution, depression of the lysocline and CCD, and an increase in the distribution of carbonates. Thus, during cold periods the Walvis Ridge area would contain widespread carbonate deposition. During the Paleocene, temperatures decreased in a steplike manner which caused intensified ocean circulation and increased biogenic production at low and mid-latitudes; the CCD deepened in the Atlantic (Kennett, 1982). It is possible that these cyclic beds, especially those at Site 528, were deposited during such a period of climatic conditions, when the CCD was located at this approximate depth. As sediments accumulated and the Walvis Ridge subsided (see site reports), the CCD must also have responded accordingly.

In addition to productivity, subsidence of the Walvis Ridge, and the position of the CCD, sea level fluctuations must also be considered (Vail et al., 1977). During this time (Cretaceous-Paleocene) a large fall in sea level followed by a gradual rise during the early Paleocene occurred. The changes in sea level appear to have occurred simultaneously on geographically separated continental shelves and are attributed to a worldwide change in sea level. Pitman (1978) suggests that these transgressions and regressions may be caused by changes in the rates of sea level change, which are related to the rate of subsidence and the rate of sediment infill. It is possible that the beds described earlier may have been deposited in response to different rates of subsidence, sedimentation rates, or slight variations in the CCD.

A third possible cause of these apparent $20 \times 10^{3} \mathrm{y}$. cycles may be biologic activity, which directly relates to oxygenated bottom-water conditions and sedimentation rates. Suppose that sediments are delivered to the deposition site in pulses, i.e., thousands of years of increased sedimentation rates, as a result of increased productivity, slumping, storms, eolian contributions, and the like. The sediments may have been oxidized subaerially 


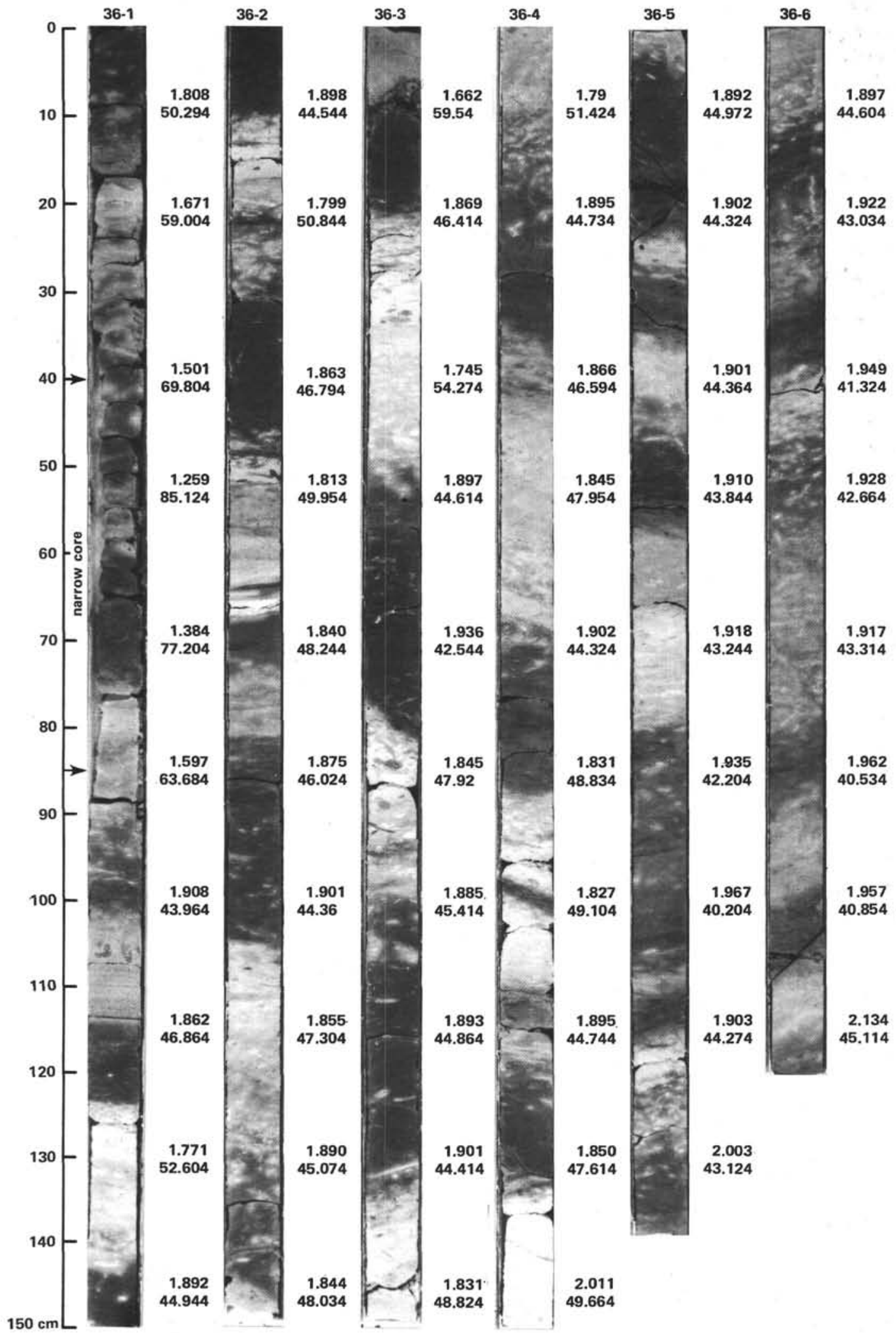

Figure 14. Geochemical cycles observed in Core 528-36. Except for a small-scale turbidite or contourite in Section 1 at approximately $110-120 \mathrm{~cm}$, this core contains alternating reddish and white intervals which are repeated approximately every $50 \mathrm{~cm}$. Boundaries are gradational, and a record of intense biogenic activity is present, especially in the white layers. The values to the right of each core section are GRAPE data. The upper value is the wet bulk density $\left(\mathrm{g} / \mathrm{cm}^{3}\right)$ and the lower value is the porosity, as a percentage. Each number represents a running average over the interval immediately above it. 
or on the ocean bottom. As the sedimentation rate decreased, the biologic organisms burrowed into the oxygenated sediment and removed the vital nutrients needed for their survival. In doing so they removed noncarbonate materials and bleached the sediment, producing an intensely burrowed light layer. Removal of the organics attached to silt and clay particles (Meyers and Keswani, this volume) for nutrients relatively enriched the remaining light layer in carbonate grains, a fact which explains the slightly higher $\mathrm{CaCO}_{3}$ percentage. As a new pulse commenced, the biologic infauna migrated closer to the sediment/water interface for oxygen. When the sedimentation rate again decreased the biologic activity became more noticeable because longer exposure of sediments in the well-oxygenated sediment zone allowed for more intense biologic ingestion and excretion.

\section{Large Scale Dissolution Cycles}

A very pronounced dissolution cycle was observed at Site 527 in Cores 13-16. This dissolution cycle corresponds with a major faunal hiatus. Core 13 is dated as being middle Miocene, whereas Cores 14-16 are early Oligocene to middle Eocene. This represents a long period when very little sediment was preserved. The two lithologies present are very dark brown to black nannofossil clay that alternates with a highly bioturbated, yellowish brown, clayey nannofossil ooze. Calcium carbonate content in the dark brown layers ranges from $1-15 \%$; in the lighter layers it is $32-56 \%$ (Fig. 15). Organic carbon is less than $0.1 \%$. Cycles vary irregularly and range in thickness from $30-160 \mathrm{~cm}$. Sedimentation rates for these intervals are 0.15 and $0.16 \mathrm{~cm} / 10^{3} \mathrm{y}$. Each couplet represents a period of from $200 \times 10^{3} \mathrm{y}$. to $1 \times 10^{6} \mathrm{y}$. However, these sedimentation rates have little meaning because the cycles are interpreted to represent dissolution events produced by a fluctuating CCD. If sedimentation were constant over the transect of sites during this time, then 150 to $180 \mathrm{~m}$ of sediment should have accumulated at Site 527 , instead of the $29.8 \mathrm{~m}$ present. (The 150 and $180 \mathrm{~m}$ are the accumulated sediment thicknesses, observed at Sites 528 and 529, respectively, that are middle Eocene to middle Miocene in age.) Apparently, $77-80 \%$ of the sediment falling to the bottom was dissolved en route or soon after deposition. The mean $\mathrm{CaCO}_{3}$ content in Cores $527-13-16$ is $41.06 \%$ (Standard deviation $= \pm 24.52$ ). The average composition of $\mathrm{CaCO}_{3}$ in oozes of this age at the other sites is greater than $90 \%$ (i.e., the noncarbonate portion is about $10 \%$ ). The amount of carbonate sediment needed to dilute a $29.8-\mathrm{m}$ thick unit containing approximately $59 \%$ noncarbonate to sediment composed of $10 \%$ noncarbonate materials is $175 \mathrm{~m}$, which agrees nicely with the estimates of thicknesses from Sites 528 and 529 . Thus for a $30 \mathrm{~m}$. y. span of time (middle Eocene-middle Miocene) a sedimentation rate of $0.58 \mathrm{~cm} / 10^{3} \mathrm{y}$. would result, changing the frequency ranges of these cycles from 50 to $275 \times 10^{3} \mathrm{y}$. It is very difficult to estimate sedimentation rates during such dissolution cycles without good biostratiographic control and until we understand more about dissolution rates in the water column and in the near-surface sediments.



Figure 15. Large-scale dissolution cycle in Core 527-14, 113.5-123.0 m sub-bottom. This core is part of the dissolution cycle observed at Site $527 . \mathrm{CaCO}_{3}$ varies but is generally very low as compared with calcareous oozes of the same age at the other sites. 


\section{Ooze/Chalk Cycles}

The first occurrence of calcareous ooze and chalk in a rhythmic sequence is at sub-bottom depths ranging from $150 \mathrm{~m}$ in Hole 527 to $270 \mathrm{~m}$ in Hole $525 \mathrm{~A}$. In Holes 528 and 529 ooze/chalk cycles are first observed at 200 and $160 \mathrm{~m}$, respectively. The age of these sediments is from early to late Oligocene in each hole. The oozes and chalks are composed of nannofossils and foraminifers with calcareous discoasters in selected areas (see Fütterer, "Pithonelloid calcareous dinoflagellates," this volume). No detailed analysis of the foraminifer/nannofossil ratio in chalks and ooze was made. The cycles repeat at intervals of between 5 and $100 \mathrm{~cm}$; frequency of repetition is in the tens of thousands of years (Table 1) but more commonly ranges from 20 to 50 $\times 10^{3} \mathrm{y}$. Contacts between the ooze and chalk are graded at the tops of the holes and become more pronounced with increasing depth, as the sediment becomes firmer and more lithified. Some of the chalks at the top of the ooze/chalk cycles are nodular in appearance. With increasing depth the oozes are lithified to chalks. Drilling obliterates and mixes much of the oozes in the upper portions of the holes. As a result, sedimentary structures in the oozes are poorly preserved, but some of the chalks show horizontal and inclined laminations and ripple marks (Fig. 16) indicating some current activity during deposition. Dispersed within many of the chalks are fine-grained volcanogenic particles. Some of the chalks themselves appear to be varved, but no detailed study of this was made. Trace fossils are also observed throughout the ooze/chalk sequences.

Results of the shipboard physical properties analyses (Table 2) indicate that when oozes and chalks are compared, the latter show an increase in wet-bulk density

Table 1. Ooze/chalk cycles: frequency of occurrence.

\begin{tabular}{ccccc}
\hline Site & $\begin{array}{c}\text { Sub-bottom } \\
\text { Depth } \\
(\mathrm{m})\end{array}$ & $\begin{array}{c}\text { Sedimentation } \\
\text { Rate } \\
\left(\mathrm{cm} / 10^{3} \mathrm{y} .\right)\end{array}$ & $\begin{array}{c}\text { Range } \\
\text { in Cycle } \\
\text { Thickness } \\
(\mathrm{cm})\end{array}$ & $\begin{array}{c}\text { Frequency } \\
\text { of } \\
\text { Occurrence } \\
\left(/ 10^{3} \mathrm{y} .\right)\end{array}$ \\
\hline 527 & $150-161$ & $0.16^{\mathrm{a}}$ & 5 & 31 \\
& & 0.58 & 50 & 300 \\
& & & 5 & 8.6 \\
& $160-208$ & 1.1 & 5 & 86.2 \\
& & & 50 & 4.5 \\
& $256-275$ & 2.2 & 50 & 22.7 \\
& & & 100 & 45.5 \\
528 & $237-256$ & 1.1 & 50 & 45.5 \\
& & & 100 & 90.9 \\
& $15-217$ & 0.5 & 10 & 20 \\
529 & & & 50 & 100 \\
& $312-360$ & 1.22 & 10 & 8 \\
& & & 50 & 22.7 \\
& $160-208$ & 1.25 & 20 & 16 \\
& $246-260$ & 0.83 & 30 & 24 \\
& $398-407$ & 1.19 & 10 & 12 \\
& & & 40 & 33.6 \\
\hline
\end{tabular}

a $0.16 \mathrm{~cm} / 10^{3} \mathrm{y}$. is very low because of a large dissolution event. This interval also contains a large biologic hiatus, so that 0.58 $\mathrm{cm} / 10^{3} \mathrm{y}$. is probably more correct. (see, for explanation, section in the text on dissolution cycles).



Figure 16. Primary sedimentary structures in chalks, Sample 528-28-2, $35-50 \mathrm{~cm}$. This chalk contains parallel and inclined laminations and bedding with beautifully preserved current ripples. Also note the alternating light and dark bedding colors, and the volcanogenic particles that are dispersed throughout the chalk. This is very similar to the $T_{c d}$ interval of Bouma (1962) and may represent a turbidite deposit.

from 1.75 to $2.00 \mathrm{~g} / \mathrm{cm}^{3}$ and horizontal sonic velocity from 1.6 to $2.0 \mathrm{~km} / \mathrm{s}$ and a decrease in porosity from 55 to $40 \%$ and wet-water content from 32 to $20 \%$, respectively. Inspection of GRAPE data (see site chapters) also substantiates these relative changes and explains the high variability observed in the GRAPE density plots in the ooze/chalk lithologic units (Figs. 2-6, back pocket).

Garrison (1981) has stated that the most important variables affecting the conversion of ooze to chalk are depth of burial and pore water chemistry, but that the 
Table 2. Results of shipboard physical properties analyses.

\begin{tabular}{ccccc}
\hline & Site & $\begin{array}{c}\text { Ooze } \\
\text { (below 50 m) }\end{array}$ & $\begin{array}{c}\text { Transition } \\
\text { Ooze/Chalk }\end{array}$ & Chalk \\
\hline Wet-bulk density & 525 & 1.75 & $1.75-2.05$ & 2.05 \\
$\mathrm{~g} / \mathrm{cm}^{3}$ & 526 & $1.7-1.75$ & - & - \\
& 527 & 1.75 & $1.75-1.9$ & $1.9-1.95$ \\
& 528 & $1.73-1.81$ & $1.81-2.0$ & $2.0-2.05$ \\
Wet water content & 529 & 1.75 & $1.75-1.9$ & $1.95-2.2$ \\
(\%) & 525 & $33-30$ & $30-22$ & $22-16$ \\
& 526 & $34-30$ & - & - \\
& 527 & 34 & $34-28$ & $28-25$ \\
Porosity (\%) & 528 & $34-37$ & $31-24$ & $24-20$ \\
& 529 & 33 & $33-26$ & $26-15$ \\
& 525 & 56 & $50-40$ & $40-35$ \\
& 526 & $60-53$ & - & - \\
Horizontal sonic & 527 & 57 & $55-50$ & 47 \\
velocity & 528 & $56-53$ & $53-45$ & $45-41$ \\
(km/s) & 525 & 55 & $55-45$ & $45-31$ \\
& 526 & 1.6 & $1.6-1.9$ & $1.9-2.6$ \\
& 527 & 1.53 & $1.55-1.7$ & 1.7 \\
& 528 & 1.55 & $1.56-1.9$ & $1.9-2.0$ \\
& 529 & 1.6 & $1.60-1.8$ & $1.8-2.5$ \\
\hline
\end{tabular}

depth at which the transformation occurs is related to the original sediment composition. I believe that the ooze/chalk cycles reflect surface conditions during the time of deposition. Further, they represent a fluctuating environment that may no longer have a modern analog. Several facts lead me to this conclusion.

The youngest sediments in the ooze/chalk cycles range in age from middle/late Oligocene to Paleogene. For oceanic current circulation patterns, the Paleogene represents the transition from latitudinal warm-water circulation at all depths to a Neogene, predominantly meridional, cold-water, thermohaline circulation pattern (Kennett, 1982). During the early Oligocene, the eastern Tethys seaway was nearly closed, thereby restricting the westward-flowing Tethys current. In addition, by the early late Oligocene a surface circumAntarctic current formed, isolating Antarctica (Kemp, 1975). The Drake Passage also opened at about $30 \mathrm{Ma}$ (Barker and Burrell, 1977) but a shallow-water passageway may have existed by latest Eocene to earliest Oligocene (Norton and Sclater, 1979). However, deep-water circulation and mixing through the Drake Passage, between the Pacific and Atlantic oceans, did not take place until the early Miocene (Barker and Burrell, 1976; Boersma and Shackleton, 1977). It was also during the Miocene that the ocean basins assumed their modern shapes (Schnitker, 1980). In the North Atlantic, the Iceland-Greenland-Faeroe Ridge subsided, allowing for exchange of cold Arctic water with the Atlantic Ocean and especially for the formation and intensification of NADW (Vogt, 1972; Schrader and others, 1976; Talwani and Eldholm, 1977, Tucholke, Vogt, et al., 1979; Schnitker, 1980). The final closure of the Tethys seaway also took place, intensifying both the northward-flowing warm waters (Gulf Stream) and southward-flowing thermohaline countercurrents.

The Paleogene-Neogene transition is also the scene of a major biogeographic change involving the develop- ment and persistence of latitudinal-dependent belts of planktonic assemblages from the tropics to the poles and a high floral and faunal diversity gradient from low to high latitudes (Kennett, 1978). Thus it appears that oceanographic conditions in the Paleogene were dramatically different from those of the Neogene.

It has been suggested by Jenkyns (1974) that most dissolution takes place at the sediment/water interface and that cyclicity is a result of the buildup of calcite supersaturation relative to the position of that interface. This is influenced by diagenetic dissolution rates of aragonite and fine-grained calcite. The formation of calcite nodules begins once the interstitial waters become supersaturated with calcite. The spacing of these nodules and eventual chalk layers depends on sedimentation rates, rates of aragonite dissolution, and the rate of $\mathrm{CaCO}_{3}$ depletion by nodular and layer growth (Muller and Fabricius, 1974). It is also evident that the primary composition of pelagic carbonate sediments influences their diagenesis (Schlanger and Douglas, 1974). These and other investigations (see Garrison, 1981, and references therein) support the concept that the "diagenetic potential" of carbonate sediments is the result of "conditioning" events which happen before burial (Schlanger and Douglas, 1974; Berger and Mayer, 1978). In the case of the Walvis Ridge ooze/chalk cycles, these conditioning events are related to fluctuating oceanographic environments that lasted for a considerable time, with a cyclic frequency in the tens of thousands of years. Since it is assumed that the pelagic sediment rain is consistent over the study area, small-scale dissolution cycles produced by fluctuating lysocline and CCD boundaries produced by changes in productivity are a most likely explanation. Dissolution events are cyclic and strongly influence grain size (Berger and Mayer, 1978) and, as previously noted, cementation and recrystallization potential. For example, relatively warm or interglacial periods would enhance dissolution, whereas cold or glacial periods would do the opposite (Mayer, 1979). It is also possible that current winnowing at regular intervals could leave slightly coarser grained sediments behind and influence the diagenetic potential of these oozes and chalks. This would help explain the fine horizontal and cross laminations that were observed in a few of the chalk specimens. The varved appearance of some of the chalks may also be explained by pulses in sediment supply, fluctuation in dissolution rates, or bottom current activity.

\section{SEDIMENT COLOR VARIATIONS AT THE CRETACEOUS/TERTIARY BOUNDARY}

The sedimentary cycles presented thus far occur on the order of tens of thousands of years. An attempt was made to determine if any larger scale cycles could be observed from the sediment cores by examining color variations within and between the cores. If large-scale cycles produced by orbital variations (Hays et al., 1976) are real, then it is possible that this may be observed both vertically and laterally within the cores in the study area. The results of the color variation study for Sites 525 , 529,528 , and 527 are shown in Figures 3-6. The major 
Table 3. $\mathrm{CaCO}_{3}$ content versus color of beds.

\begin{tabular}{lc}
\hline \multicolumn{1}{c}{ Color } & $\begin{array}{c}\text { Average Range } \\
\text { in } \mathrm{CaCO}_{3} \\
(\%)\end{array}$ \\
\hline Red or red brown & $5-15$ \\
Green & $10-40$ \\
Black or dark brown & $1-20$ \\
Medium brown & $50-80$ \\
Light brown & $70-90$ \\
White & $70-100$ \\
Blue-white & $>90$ \\
Pale orange & $80-95$ \\
\hline
\end{tabular}

color categories present in the cores are white, pale orange, blue white, light brown, medium brown, dark brown to black, green, and red brown to red. The exact colors as described by the GSA Rock Color Chart are shown in the core barrel sheets in the site chapters.

The ranges of $\mathrm{CaCO}_{3}$ content in the colored beds are given in Table 3 . Red and black beds have the least amount of $\mathrm{CaCO}_{3}$ followed by green and medium brown. The rest of the colors are associated with carbonate oozes and chalks which contain abundant $\mathrm{CaCO}_{3}$, averaging approximately $90 \%$. Organic carbon in all of the beds is less than $1 \%$. Boundaries between color are very distinct in the older sediments in the lower portions of the cores. In the upper (younger) section of the cores, colors are more gradational and vague, excluding the large-scale dissolution cycles, which have distinct color boundaries.

The major conclusion of this preliminary analysis is that these color variations are cyclic in nature on a centimeter to meter scale but that they are localized and restricted to certain depth intervals and cores. No single cyclic color pattern can be correlated across the entire transect. Whatever physical or chemical conditions produced the alternating color patterns were localized and did not exist over the entire area.

The greatest color variation occurs in Upper Cretaceous to lower Paleocene sediments, near the Cretaceous/Tertiary boundary. At the shallow Site 525 reddish beds alternate with light brown and white beds. Green sediments are more abundant deeper in the core and may reflect anoxic conditions over the Walvis Ridge during the late Campanian (Liu and Schmitt, this vol.). The next shallowest Site 529 contains only green sediments alternating with light and medium brown sediments. The Cretaceous/Tertiary boundary at Site 528, located at greater water depth than 529 , contains both red and green beds alternating with white and with light and medium-colored sediments. Lastly, the site in the deepest water, Site 527, contains only red beds alternating with brown, black, pale orange, and white beds. No green colors are observed. We have discussed the origin of the sediments within this interval in previous sections. They are primarily slump deposits and turbidites. However, I think the colors are independent of the sediment origin unless some mechanism exists to deliver red sediments to the shallow and deep sites and green sediments to the intermediate sites (Fig. 17). Bimodal source areas are possible but unlikely. I suggest that the colors reflect bottom-water conditions which existed for a very short period of time, particularly at the Cretaceous/Tertiary boundary. In fact, based on sedimentation rates, the duration of the red bed event ranges from 225 to $1250 \times 10^{3}$ y. at Site $527,832 \times$ $10^{3} \mathrm{y}$. at Site 528 and $338 \times 10^{3} \mathrm{y}$. in Hole 525A. The first and most obvious explanation is that the red and green colors represent fluctuating Eh conditions in the sediments. Marcasite nodules (e.g., Core 525A-46, back-pocket Fig. 8) occur in the green turbidite and slump beds and suggest reducing conditions. No iron sulfide minerals were found in the Fe-oxide-stained red beds. Realizing that the water depths at these sites for the time ranged from upper bathyal to bathyal (Boersma, this volume), it is possible to envision a densitystratified system consisting of oxygenated surface or intermediate and bottom water with an anoxic water mass located between them (Fig. 17). This condition was temporary: it lasted on the order of $10^{5} \mathrm{y}$. and has not been repeated since.

The exact cause for the terminal Cretaceous event is unknown, but many hypotheses have been proposed (Schindewolf, 1954; Newell, 1962, Bramlette, 1965; Simpson, 1966; Tappan, 1968; Vogt, 1972, Worsley, 1974; Gartner and Keany, 1978; Smit and Hertogen, 1980; Emiliani, 1980; Kerr, 1980; Alvarez et al., 1980; Alvarez et al., 1982). Whether or not this temporary condition found in the Walvis Ridge-Angola Basin can be correlated to one or more of these hypotheses is the subject for future work.

\section{CONCLUSIONS}

The sediments recovered from the Walvis Ridge-Angola Basin consist (in descending order) of oozes, chalks, limestones, and volcaniclastic sedimentary rocks ranging from breccias to clays. They represent shallow- to deep-water environments. Some of these volcaniclastic sediments and limestones are interbedded with basalts, forming a basement complex. These sediments and rocks can be correlated from hole to hole with the exception of Site 526, the shallowest site, which was under a different depositional regime during much of the Cenozoic.

These sediments were deposited in cycles that were dominant but not exclusive during discrete intervals in geologic time. Superimposed on these cycles are diagenetic and/or biological effects which have altered the original character of the sediments. The findings of this chapter relating to the distinguishing characteristics and origin of these sediments and cycles include:

1) Turbidites, found in Lithologic Units III and IV (Late Cretaceous-Paleocene) are the most frequently occurring cycle, with recurrence intervals of thousands to tens of thousands of years. The turbidites are composed of approximately equal proportions of carbonate and noncarbonate minerals and are easily distinguished from the other cyclic sediments on the basis of sedimentary structures, mineralogy, alteration products, and physical property GRAPE data. Large-scale turbidite or 

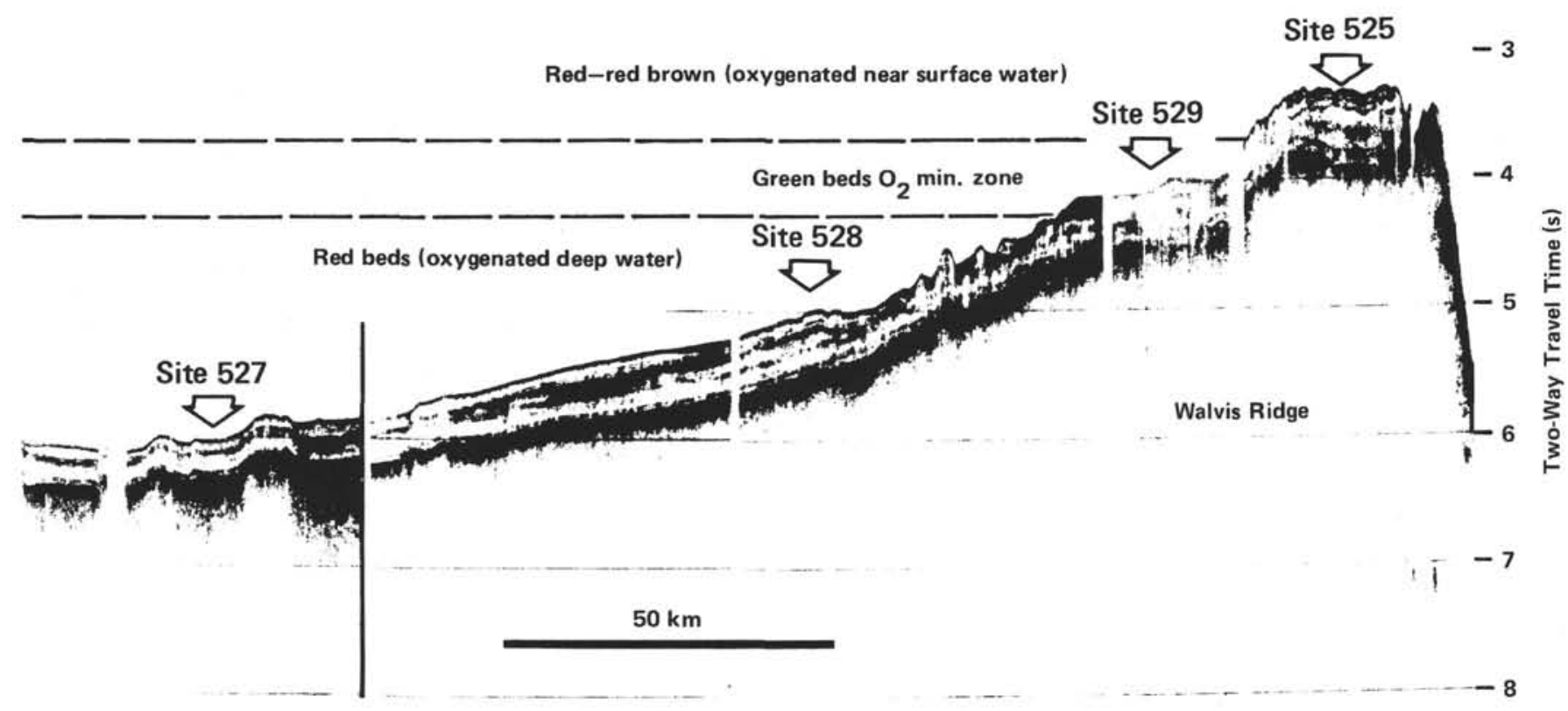

$50 \mathrm{~km}$

Figure 17. Sediment color variation versus water depth, early Paleocene to Late Cretaceous.

slump breccias are found at or just above the Cretaceous/Tertiary boundary, indicating intense tectonic activity.

2) Early Paleocene diagenetic cycles are small-scale and alternate over tens of centimeters, with recurrence intervals in tens of thousands of years, commonly averaging $20 \times 10^{3} \mathrm{y}$. These cycles can be distinguished on the basis of variation in $\mathrm{CaCO}_{3}$ content, gradational boundaries, color, biogenic activity, and to a lesser extent physical properties. These repeating sequences are interpreted as small-scale dissolution cycles or cycles produced by biogenic activity, both of which are the direct result of sedimentation rates, productivity, position of the CCD, and fluctuating oxygen content in bottom waters. These in turn are dependent upon climatic conditions.

3) The ooze/chalk cycles occur in upper Oligocene to upper Paleocene sediments. Although depth of burial and pore water chemistry are primarily responsible for the transformation of ooze to chalk, the "diagenetic potential" of the ooze/chalk cycles is obtained while the sediments are at the sediment/water interface (Garrison, 1981; Schlanger and Douglas, 1974). Judging by sedimentation rates, these cycles represent oscillations in the marine environment that occurred over tens of thousands of years. Present-day thermohaline circulation of ocean water is thought to have commenced in the early Miocene; thus these ooze/chalk cycles may represent an oscillating environment with no modern (Neogene) counterpart. Older sediments in the cores may have had a similar history of oscillations, but this cannot be determined. The record of the environment existing at the time of deposition may have been completely destroyed by diagenesis in these older deposits.

4) Variations in color of sediments at the Cretaceous/Tertiary boundary indicate local fluctuations in bottom to upper bathyal water masses. An oxidized red pigment at the deepest and shallowest sites, and a green pigment, representing reducing conditions, at the intermediate-depth site may indicate a water system stratified with respect to oxygen. This environment lasted on the order of $225-1000 \times 10^{3} \mathrm{y}$. and has not been repeated since the earliest Paleocene.

5) Large-scale dissolution cycles occurred at Site 527 during the middle Miocene and from early Oligocene to middle Eocene; $\mathrm{CaCO}_{3}$ content was drastically reduced. It is estimated that as much as $175 \mathrm{~m}$ of carbonate material was dissolved en route or at the sediment/water interface during this time span. Site 527, the site having the greatest water depth, appears to have been at a depth occupied by a fluctuating CCD and lysocline during this time.

6) Below a reduced thickness of oozes and chalks, Site 526 contains a series of redeposited shallow-water carbonates, composed of oysters, pelecypods, and algal oncolites, overlying immature sands composed of shallow-water carbonate and noncarhonate grains. Both sediment types indicate very shallow, agitated water conditions at or near this area during the late EoceneOligocene.

\section{ACKNOWLEDGMENTS}

I am grateful for the opportunity to have participated on Leg 74 of the Deep Sea Drilling Project. I am especially thankful to my fellow shipboard scientists whose hard work, careful descriptions, and suggestions brought my attention to these various sedimentary cycles. P. Rabinowitz, T. C. Moore, and R. Lindholm reviewed preliminary drafts of this manuscript. Liz L. Huey kindly typed and edited all versions of the manuscript.

\section{REFERENCES}

Alvarez, L. W., Alvarez, W., Asaro, F., and Michel, H. V., 1980. Extraterrestrial cause for the Cretaceous-Tertiary extinction. Science, 208:1095-1108.

Alvarez, W., Asaro, F., Michel, H. V., and Alvarez, L. W., 1982. Major impacts and their geological consequences. Geol. Soc. Am., 95th Ann. Meeting, pp. 431-432 (Abstract).

Bader, R. G., Gerard, R. D., et al., 1970. Init. Repts. DSDP, 4: Washington (U.S. Govt. Printing Office). 
Barker, P. F., and Burrell, J., 1976. The opening of Drake Passage. Proc. Joint Oceanogr. Assembly: Rome (Food and Agricultural Organization of the United Nations), p. 103. $15-34$

1977. The Opening of Drake Passage. Mar. Geol., 25:

erger, W. H., and Mayer, L. A., 1978. Deep Sea Carbonates: Acoustic Reflectors and Lysocline Fluctuations. Geology, 6:11-15.

Bischoff, J. L., and Dickson, F. W., 1975. Sea water-basalt interaction at $200 \mathrm{c}$ and 500 bars: Implications for origin of sea floor heavy metal deposits and regulation of sea water chemistry. Earth Planet. Sci. Lett., 25:385-397.

Boersma, A., and Shackleton, N., 1977. Tertiary oxygen and carbon isotope stratigraphy, Site 357 (Mid-latitude South Atlantic). In Supko, P. R., Perch-Nielsen, K., et al., Init. Repts. DSDP, 39: Washington (U.S. Govt. Printing Office), 911-924.

Borella, P. E., Meyers R., and Mills, W., 1983. Petrology of the hydrothermal mound sediments. In Honnorez, J., von Herzen, R. H., et al., Init. Repts. DSDP, 70:197-210.

Bouma, A. H., 1962. Sedimentology of Some Flysch Deposits: A Graphic Approach to Facies Interpretation: Amsterdam (Elsevier).

Bouma, A. H., and Hollister, C. D., 1973. Deep ocean basin sedimentation. In Middleton, G. V., and Bouma, A. H. (Eds.), Turbidites and Deep Water Sedimentation. Soc. Econ Paleontol. Mineral. Pacific Sect., pp. 79-118.

Boyce, R. E., and Bode, G. W., 1972. Carbon and carbonate analyses, Leg 9, Deep Sea Drilling Project. In Hays, J. D., et al. Init. Repts. DSDP, 9: Washington (U.S. Govt. Printing Office), 747.

Bramlette, M. N., 1965. Massive extinctions in biota at the end of Mesozoic time. Science, 148:1696-1699.

Dean, W. E., Gardner, J. V., Jansa, L. F., Cepek, P., and Siebold, E., 1978. Cyclic sedimentation along the continental margin of North Africa. In Lancelot, Y., Seibold, E., et al., Init. Repts. DSDP, 4: Washington (U.S. Govt. Printing Office). 965-990.

Dunham, R. J., 1962. Classification of carbonate rocks according to depositional texture. In Ham, W. E. (Ed.), Classification of Carbonate Rocks. Am. Assoc. Pet. Geol. Mem., 1:108-121.

Emiliani, C., 1980. Death and renovation at the end of the Mesozoic. EOS, Am. Geophys. Un. Bull., 61:505-506.

Folk, R. L., 1962. Spectral subdivision of limestone types. In Ham, W. E. (Ed.), Classification of Carbonate Rocks. Am. Assoc. Pet. Geol., Mem., 1:62-84.

Garrison, R. E., 1981. Diagenesis of oceanic carbonate sediments: A review of the DSDP perspective. In Warme, T. E., Douglas, R. C., and Winterer, E. L. (Eds.), The Deep Sea Drilling Project: A Decade of Progress. Soc. Econ. Paleontol. Mineral., Spec. Publ., 32: 181-207.

Gartner, S., and Keany, J., 1978. The terminal Cretaceous event: A geologic problem with an oceanographic solution. Geology, 6: 708-712.

Gieskes, J. M., 1981. Deep Sea Drilling interstitial water studies: Implications for chemical alteration of oceanic crust, Layers I and II. In Warme, T. E., Douglas, R. C., and Winterer, E. L. (Eds.), The Deep Sea Drilling Project: A Decade of Progress. Soc. Econ. Paleont. Mineral., Spec. Publ., 32:149-167.

Gieskes, J. M., and Lawrence, J. R., 1981. Alteration of volcanic matter in deep sea sediments: Evidence from the chemical composition of interstitial waters from deep sea drilling cores. Geochim. Cosmochim. Acta, 45:1687-1703.

Hays, J. D., Imbrie, J., and Shackleton, N. J., 1976. Variations in the earth's orbit: Pacemaker of the ice ages. Science, 194:1121-1132.

Hollister, C. D., and Heezen, B. C., 1972. Geologic effects of oceanbottom currents: Western North Atlantic. In Gordon and Breach (Eds.), Studies in Physical Oceanography (Vol. 2):0000, 37-66.

Jenkyns, H. C., 1974. Origin of red nodular limestones (Ammonitico Rosso, Knollenkalke) in the Mediterranean Jurassic: A diagenetic model. In Hsü, K. J. and Jenkyns, H. C. (Eds.), Pelagic Sediments on Land and under the Sea. Int. Assoc. Sedimentol., Spec. Publ., $1: 249-271$.

Kelts, K., and Arthur, M. A., 1981. Turbidites after ten years of deep sea drilling - wringing out the mop? In Warme, T. E., Douglas, R. C., and Winterer, E. L. (Eds.), The Deep Sea Drilling Project: $A$ Decade of Progress. Soc. Econ. Paleontol. and Mineral., Spec. Publ., 32:91-127.

Kemp, E. M., 1975. Palynology of Leg 28 Drill sites, Deep Sea Drilling Project. In Hayes, D. E., Frakes, L. A., et al., Init. Repts. $D S D P, 28$ : Washington (U.S. Govt. Printing Office), 599-623.
Kennett, J. P., 1978. The development of planktonic biogeography in the Southern Ocean during the Cenozoic. Mar. Micropaleontol., 3:301-345. Hall).

1982. Marine Geology: Englewood Cliffs, N.J. (Prentice-

Kerr, R. A., 1980. Asteroid theory of extinctions strengthened. Science, 210:514-517.

Kolla, V., Moore, D. G., and Wray, J. R., 1976. Recent bottom current activity in the deep western Bay of Bengal. Mar. Geol., 21: 255-270.

Lawrence, J. R., and Gieskes, J. M., 1981. Constraints on water transport and alteration in the oceanic crust from the isotopic composition of pore water. J. Geophys. Res., 86:7924-7934.

McDuff, R. E., 1981. Major cation gradients in DSDP interstitial waters: The role of diffusive exchange between sea water and upper oceanic crust. Geochim. Cosmochim. Acta, 45:1705-1713.

Mayer, L. A., 1979. Deep sea carbonates: Acoustic, physical and stratigraphic properties. J. Sed. Petrol., 49:819-836.

Milankovitch, M., 1938. Astronomische Mittel zur Erforschung der erdgeschichtlichen Klimate. Handb. Geophys., 9:593-698.

Moore, T. C., Rabinowitz, P. D., Boersma, A., Borella, P. E., Chave, A. D., Duee, G., Futterer, D. K., Jiang, M.-J., Kleinert, K., Lever, A., Manivit, H., O'Connell, S., Richardson, S. H., Shackleton, N. J., in press. Preliminary results of the Deep Sea Drilling Project Leg 74-Walvis Ridge transect. Geol. Soc. Am. Bull.

Muller, J., and Fabricius, F., 1974. Magnesian calcite nodules in the Ionian deep sea - an actualistic model for the formation of some nodular limestones. In Hsü, K. J., and Jenkyns, H. C., Eds., Pelagic Sediments: On Land and under the Sea. Int. Assoc. Sedimentol., Spec. Publ., 1:235-247.

Newell, N. D., 1962. Paleontologic gaps and geochronology. J. Paleontol., 36:592-610.

Norton, I. O., and Sclater, J. G., 1979. A model for the evolution of the Indian Ocean and the breakup of Gondwanaland. J. Geophys. Res., 84:6803-6830.

Piper, D. J. W., 1973. The sedimentology of silt turbidites from the Gulf of Alaska. In Kulm, L. D., von Huene, R., et al., Init. Repts. DSDP, 18: Washington (U.S. Govt. Printing Office), 847-868.

1978. Turbidite muds and silts on deep sea fans and abyssal plains. In Stanley, D. J., and Kelling, G. (Eds.), Sedimentation in Submarine Canyons, Fans and Trenches: Stroudsburg, Pa. (Dowden, Hutchinson and Ross), pp. 163-176.

Pisciotto, K. A., 1981. Distribution, thermal Histories, isotopic compositions, and reflection characteristics of siliceous rocks recovered by the Deep Sea Drilling Project. In Warme, T. E., Douglas, R. G., and Winterer, E. L. (Eds.), The Deep Sea Drilling Project: A Decade of Progress. Soc. Econ. Paleont. Mineral., Spec. Publ., 32:129-147.

Pitman, W. C., III, 1978. Relationship between eustacy and stratigraphic sequences of passive margins. Geol. Soc. Am. Bull., 89: 1389-1403.

Rabinowitz, P. D., and Simpson, E. S. W., 1979. Results of IPOD Site surveys aboard $R / V$ Thomas B. Davie: Walvis Ridge Survey. LDGO Tech. Rept., JOI, Inc.

Ramsay, A. T. S., 1974. The distribution of calcium carbonate in deep sea sediments,. Soc. Econ. Paleontol. Mineral., Spec. Publ., 20: 58-76.

Rupke, N. A., and Stanley, D. J., 1974. Distinctive properties of turbidite and hemipelagic mud layers in the Algero-Balearic Basin, western Mediterranean Sea. Smithsonian Contrib. Earth Sci., 13:40.

Schindewolf, O. H., 1954. Uber die moglichen Ursachen der grossen Erdges chechtlichen Fraunenschnitte. N.Jb. Geol. Palaont., Monatsh., 457-465.

Schlanger, S. O., and Douglas, R. G., 1974. The pelagic ooze-chalklimestone transition and its implications for marine stratigraphy. In Hsü, K. J., and Jenkyns, H. C. (Eds.), Pelagic Sediments: On Land and under the Sea. Int. Assoc. Sed., Spec. Publ., 1:117-148.

Schnitker, D., 1980. Quaternary deep-sea benthic foraminifers and bottom water masses. Ann. Rev. Earth Planet. Sci., 8:343-370.

Schrader, H. J., Bjørklund, K., Manum, S., Martini, E., and van Hinte, J., 1976. Cenozoic biostratigraphy, physical stratigraphy and Paleoceanography in the Norwegian-Greenland Sea, DSDP Leg 38: Paleontological synthesis. In Talwani, M., Udintsev, G., et al., Init. Repts. DSDP, 38: Washington (U.S. Govt. Printing Office), $1197-1211$ 
Simpson, J. F., 1966. Evolutionary pulsations and geomagnetic polarity. Geol. Soc. Am. Bull., 77:227-234.

Smit, J., and Hertogen, J., 1980. An extraterrestrial event at the Cretaceous-Tertiary boundary. Nature, 285:198-200.

Stow, D. A. U., 1979. Method for silt and fabric analysis in deep sea cores. J. Sed. Petrol., 49:627-630.

Stow, D. A. U., and Lovell, J. P. B., 1979. Contourites: Their recognition in modern and ancient sediments. Earth Sci. Rev., 14: 251-291.

Talwani, M., and Eldholm, O., 1977. Evolution of the NorwegianGreenland Sea. Geol. Soc. Am. Bull., 88:969-999.

Tappan, H., 1978. Primary production, isotopes, extinctions and the atmosphere. Palaeogr., Paleoclimatol., Palaeoecol., 4:187-210.

Tucholke, B. E., Vogt, P. R., et al., 1979. Init. Repts. DSDP, 43: Washington (U.S. Govt. Printing Office).
Vail, P. R., Mitchum, R. M., Jr., and Thompson, S., III, 1977. Global cycles of relative changes of sea level. In Payton, C. E. (Ed.), Seismic Stratigraphy-Applications to Hydrocarbon Exploration. Am. Assoc. Pet. Geol. Mem., 26:83-97.

Vogt, P. R., 1972. The Faeroe-Iceland-Greenland Aseismic Ridge and the Western Boundary undercurrent. Nature, 239:189-191.

Walker, R. C., 1967. Turbidite sedimentary structures and their relationship to proximal and distal depositional environments, J. Sed. Petrol., 37:24-43.

Walker, R. C., and Mutti, E., 1973. Turbidite facies and facies associations. In Middleton, G. V., and Bouma, A. H. (Eds.), Turbidites and Deep Water Sedimentation. Soc. Econ. Paleontol. Mineral. Pacific Sect., pp. 119-157.

Worsley, T., 1974. The Cretaceous-Tertiary Boundary event in the ocean. Soc. Econ. Paleontol. Mineral., Spec. Publ., 20:94-120. 